\title{
PENGARUH KOMUNIKASI TERAPEUTIK PERAWAT TERHADAP TINGKAT KECEMASAN ORANG TUA PASIEN SEBELUM TONSILEKTOMI
}

\author{
Alfiery Leda Kio ${ }^{1, *}$, I Wayan Artana ${ }^{2}$, Ni luh Putu Mastini ${ }^{3}$ \\ STIKES Bina USada Bali ${ }^{1,2}$ \\ RSD Mangusada Badung ${ }^{3}$ \\ e-mail: kioalfieryleda@gmail.com
}

\begin{abstract}
Inflammation of the tonsils either caused by viruses or bacteria that cause acute tonsillitis if not experiencing complete healing can develop into chronic tonsillitis. The action that is often done in chronic tonsillitis is tonsillectomy. The management of tonsillectomy has psychological consequences on the patient and his family including anxiety. Anxiety can be reduced by nursing actions that focus on therapeutic communication for patients and their families. Objective: The study aims to determine the effect of nurses' therapeutic communication on the anxiety level of parents of patients before tonsillectomy in Mangusada Badung Hospital. Method: The design used was pre experimental pre-post desing test. The sample is the parent of the patient who is going to undergo a tonsillectomy. Data were collected using a HARS questionnaire before and after therapeutic communication. Data were analyzed using the Wilcoxon Test. Results: The results of the study of the average respondent had a moderate level of anxiety before therapeutic communication and the level of anxiety decreased after therapeutic communication. Conclusion: of the research is that there is a significant and significant effect of therapeutic communication on the reduction of respondents' anxiety levels before their children undergo tonsillectomy at the Mangusada Badung Regional Hospital p $(0.001<\alpha 0.05)$.
\end{abstract}

Keywords: Therapeutic Communication, Anxiety, Tonsillectomy

\begin{abstract}
ABSTRAK
Latar Belakang: Peradangan pada tonsil baik disebabkan oleh virus maupun bakteri yang menimbulkan tonsillitis akut jika tidak mengalami penyembuhan sempurna bisa berkembang menjadi tonsillitis kronik. Tindakan yang sering dilakukan pada tonsilitis kronis adalah tonsilektomi. Penatalaksanaan tonsilektomi membawa konsekuensi psikologis pada pasien dan keluarganya diantaranya muncul rasa kecemasan. Kecemasan dapat dikurangi dengan tindakan keperawatan yang berfokus pada komunikasi terapeutik bagi pasien dan keluarganya. Tujuan: Penelitian bertujuan mengetahui pengaruh komunikasi terapeutik perawat terhadap tingkat kecemasan orang tua pasien sebelum tonsilektomi di RSD Mangusada Badung. Metode: Rancangan yang digunakan pre eksperiment pre-post test desing. Sampel adalah orangtua pasien yang akan ditonsilektomi. Data dikumpulkan menggunakan kuesioner HARS sebelum dan setelah dilakukan komunikasi terapeutik. Data dianalisis menggunakan Uji Wilcoxon. Hasil: Hasil penelitian rata-rata responden mempunyai tingkat kecemasan yang sedang sebelum dilakukan komunikasi terapeutik dan tingkat kecemasannya berkurang setelah komunikasi terapeutik. Kesimpulan: Ada pengaruh yang signifikan dan bermakna komunikasi terapeutik terhadap penurunan tingkat kecemasan responden sebelum anaknya dilakukan tindakan tonsilektomi di RSD Mangusada Badung $\mathrm{p}(0,001<\alpha, 0,05)$.
\end{abstract}

Kata kunci: Komunikasi Terapeutik, Kecemasan, Tonsilektomi

\section{PENDAHULUAN}

Kesehatan tenggorok masih menjadi masalah di Indonesia. Kurangnya pengetahuan dan perilaku hidup sehat menjadi salah satu faktor timbulnya penyakit tenggorok terutama faringitis dan tonsilitis (Setephany, 2016). Beberapa laporan ilmiah di dalam dan di luar negeri menunjukkan bahwa masalah kesehatan di bidang otorhinolaringology atau ilmu kesehatan Telinga Hidung Tenggorokan (THT) pada tonsil dan adenoid merupakan penyakit yang umumnya paling sering ditemukan pada masyarakat (Turnip, 2015) . 
Tonsilitis kronis dalam satu studi dilaporkan di Negara Norwegia, anak-anak yang menderita tonsilitis sekitar $11,7 \%$ sedangkan anak-anak yang berada di Negara Turki dilaporkan sekitar 12,1\% (Srikandi, 2013). Menurut Rikesdes (2013) prevalensi tonsilitis kronis sebesar $4.8 \%$ tertinggi kedua setelah nasofaring akut 5,6\%. Berdasarkan data epidemiologi bulan September 2018 penyakit THT di Indonesia, prevalensi tonsilitis menduduki urutan kedua setelah nasofaringitis akut (Itje Sela \& Hartati, 2012). Data klinik THT RSD Mangusada pada tahun 2017 jumlah pasien tonsilitis sebanyak 845 orang dan dilakukan tonsilektomi 390 orang $(46,1 \%)$ Sedangkan di tahun 2018 jumlah pasien tonsilitis yang ditangani adalah 795 orang dan yang dilakukan tonsilektomi adalah 420 orang (52,8\%). Sampai dengan akhir Mei 2019 jumlah pasien tonsillitis yang ditangani adalah 425 orang dan yang dilakukan tonsilektomi adalah 210 orang $(49,4 \%)$. Bila dirata-ratakan jumlah pasien tonsillitis yang ditangani per bulan adalah 70 orang dan yang dilakukan tonsilektomi adalah 34 orang (48\%).

Tindakan yang sering dilakukan pada tonsilitis kronis adalah operasi pengangkatan tonsil atau tonsilektomi. Tonsilektomi merupakan prosedur bedah untuk menyingkirkan tonsil secara keseluruhan, termasuk kapsul dengan cara diseksi ruang peritonsiler antara kapsul tonsil dan dinding muskuler (Tanjung, 2016). Tonsiledektomi dilakukan ketika tonsilitis akut berurang, slepp disordered breating yang biasanya ditandai dengan mendengkur dan infeksi telinga bagian tengah (Subramanyam, 2013). Tindakan tonsilektomi menyebabkan masalah jangka pendek dan jangka panjang dimana masalah yang segera terjadi setelah operasi yaitu terasa panas pada tenggorokan dan nyeri menelan, sedangkan masalah jangka panjang yaitu gangguan sistem imun dan peningkatan resiko terjadinya beberapa penyakit (Aprilia, 2018).

Pencetus terjadinya kecemasan antara lain adalah penyakit kronis, trauma fisik, dan pembedahan. Pembedahan tersebut dapat dialami oleh siapa saja termasuk anak-anak. Penatalaksanaan tonsilektomi membawa konsekuensi psikologis, fisiologis, dan anatomis. Konsekuensi psikologis yang didapat pasien dan keluarganya diantaranya muncul rasa kecemasan (Lubis \& Afif, 2014). Setiap tahun diperkirakan sebesar 234 juta operasi dilakukan di seluruh dunia (Kementrian Kesehatan RI, 2011). Diperkirakan 6 juta anak menjalani operasi dan anestesi setiap tahun di Amerika Serikat, sehingga penilaian perilaku dan klinis anak dan orang tua yang menjadi perhatian penting. Kebanyakan orang tua mengalami kecemasan dan ketakutan saat pre operasi (Babazade, Dogangun, Bozkurt, Gungor, \& Kayaalp, 2015). Kecemasan merupakan respon normal yang terjadi dalam situasi stress. Namun, yang menjadi masalah adalah kecemasan tersebut memberikan dampak terhadap suasana hati dan komunikasi orang tua, bahkan juga akan berdampak pada anak pre operasi (Shirley, Thompson, Kenward \& Johnston, 2010). Orang tua yang secara psikologi mengalami cemas, akan sulit untuk melakukan komunikasi dan menerima informasi umum (Lubis \& Afif, 2014).

Riset Kesehatan Dasar (Riskesdas) tahun 2013, dilaksanakan oleh Badan Penelitian dan Pengembangan Kesehatan Kementrian Kesehatan RI menunjukkan prevalensi gangguan mental termasuk kecemasan pada umur $\geq 15$ tahun di Indonesia yaitu $6 \%$ dari jumlah penduduk di 2013. Keadaan ini meningkat menjadi 9,8\% di 2018. Artinya, jumlah penderita kecemasan di Indonesia juga meningkat. Pravelensi gangguan kecemasan paling tinggi terdapat di Provinsi Sulawesi Tengah sebesar $11,6 \%$ dan terendah di Lampung sebesar 1,2\%. Provinsi Bali juga mengalami hal yang sama yaitu peningkatan jumlah penderita gangguan kecemasan dari 5\% di 2013 menjadi 8\% di 2018. Peningkatan jumlah kelainan mental ini berarti juga meningkatkan kejadian kecemasan di Bali (Kemenkes RI, 2018).

Kecemasan dapat dikurangi dengan tindakan keperawatan yang berfokus pada komunikasi terapeutik bagi pasien dan keluarganya (Liza, 2014). Komunikasi terapeutik mengembangkan hubungan interpersonal antara klien dan perawat. Proses ini meliputi kemampuan khusus, karena perawat harus memperhatikan pada berbagai interaksi dan tingkah laku non-verbal (Potter \& Perry, 2013). Perawat dan tenaga medis sering lebih berfokus pada individu pasien dalam melakukan tindakan sehingga mengabaikan kecemasan orang tua. Dukungan perawat dalam hal pemberian informasi pre operasi kepada orang tua juga sangat penting. (Sigalingging, 2013). Komunikasi terapeutik merupakan komunikasi yang dilakukan perawat dengan pasien atau perawat dengan keluarga pasien yang didasari oleh hubungan saling percaya yang didalam komunikasi tersebut terdapat seni penyembuhan yaitu mengatasi kecemasan (Nasir, 2011). Komunikasi terapeutik 
merupakan komunikasi antar tenaga kesehatan dengan pasien, atau orang tuanya bertujuan untuk mendorong proses penyembuhan pasien (Susilo, 2011).

Beberapa penelitian yang telah membuktikan adanya hubungan antara komunikasi terapeutik dengan kecemasan adalah penelitian Riski \& Lestari (2017) tentang komunikasi terapeutik perawat dengan tingkat kecemasan keluarga pasien di ruang THT General Hospital (RSUD) Ratu Zalecha Martapura. Pada penelitian ini ditemukan komunikasi terapeutik perawat berhubungan dengan tingkat kecemasan keluarga pasien $(p=0,000<0,05)$. Penelitian oleh Arifah \& Trise (2012) tentang pengaruh pemberian informasi tentang persiapan operasi dengan pendekatan komunikasi terapeutik terhadap tingkat kecemasan pasien pre operasi di ruang Bougenville RSUD Sleman di Rumah Sakit Jiwa Ghrasia Jogyakarta tahun 2012. Pada penelitian ini ditemukan bahwa sebanyak 46,7\% responden mengalami kecemasan ringan, $51,1 \%$ mengalami kecemasan sedang, dan kecemasan berat $2,2 \%$ sebelum pemberian komunikasi terapeutik. Setelah pemberian komunikasi terapeutik tingkat kecemasannya menjadi ringan $82,2 \%$, tingkat kecemasan sedang $4,4 \%$, dan yang menjadi tidak cemas sebesar $13,3 \%$. Penelitian ini, dengan uji statistik Wilcoxon menunjukkan bahwa pemberian komunikasi terapeutik mempunyai pengaruh yang signifikan dalam menurunkan kecemasan pasien $(\mathrm{p}=0,001 ; \alpha=$ $0,05)$.

Berdasarkan hasil studi pendahuluan yang dilakukan peneliti pada tanggal 11 - 16 Juni 2019 di Klinik THT, terdapat 13 anak yang dilakukan tonsilektomi. Dari 13 orang terdapat dua orang tua pasien yang tidak mengalami kecemasan $(15,4 \%)$, empat orang tua pasien mengalami kecemasan ringan $(30.7 \%)$, lima orang tua pasien mengalami kecemasan sedang $(38,5 \%)$, seorang mengalami kecemasan berat $(7,7 \%)$, dan satu orang mengalami kecemasan panik $(7,7 \%)$.

Berdasarkan pemaparan latar belakang masalah di atas membuat peneliti sangat tertarik untuk meneliti pengaruh komunikasi terapeutik perawat terhadap tingkat kecemasan orang tua pasien sebelum tonsilektomi di RSD Mangusada Badung..

\section{METODE}

Jenis penelitian ini adalah penelitian kuantitatif dengan metode eksperimental khususnya pre eksperimental, karena tidak memakai kelompok kontrol. Dengan rancangan Pre-test and Post-test Only One Group Design. Penelitian ini sudah mendapatkan surat persetujuan uji etik oleh Komisi Etik STIKES Bina Usada Bali dengan no: 391/ EA/KEPKBUB-2019. Sampel dalam penelitian ini adalah 31 responden. Teknik pengambilan sampel berdasarkan Incidental sampling. Alat pengumpulan data dengan kuisoner Hamilton Rating Scale for Anxiety. Pada penelitian ini pengolahan data akan menggunakan program SPSS, data kecemasan sebelum dan setelah diberikn komunikasi terapeutik diuji dengan uji Wilcoxon.

\section{HASIL}

\section{Karakteristik Responden Berdasarkan Jenis Kelamin}

Tabel 1

Distribusi Frekuensi Responden Berdasarkan Jenis Kelamin

\begin{tabular}{lcc}
\hline $\begin{array}{l}\text { Tingkat } \\
\text { Pendidikan }\end{array}$ & Frekuendi (f) & $\begin{array}{c}\text { Presentase } \\
(\%)\end{array}$ \\
\hline Laki-laki & 20 & 65 \\
Wanita & 11 & 35 \\
\hline Total & 31 & 100 \\
\hline
\end{tabular}

Pada tabel 1 menunjukkan sebagian besar responden yang berjenis kelamin laki-laki sebanyak 20 orang $(65 \%)$.

\section{Karakteristik Responden Berdasarkan Pendidikan}

Tabel 2

Distribusi Frekuensi Responden Berdasarkan Tingkat Pendidikan

\begin{tabular}{lcc}
\hline $\begin{array}{l}\text { Tingkat } \\
\text { Pendidikan }\end{array}$ & Frekuensi (f) & $\begin{array}{c}\text { Persentase } \\
(\%)\end{array}$ \\
\hline SMP & 10 & 32 \\
SMA sederajat & 15 & 48 \\
Perguruan tinggi & 6 & 20 \\
\hline Total & 31 & 100 \\
\hline
\end{tabular}

Pada tabel 5.2 menunjukkan tingkat pendidikan responden terbanyak adalah SMA sederajat yaitu 15 orang $(48 \%)$. 


\section{Karakteristik Responden Berdasarkan Jenis Pekerjaan}

Tabel 3

Distribusi Frekuensi Responden Berdasarkan Jenis Pekerjaan

\begin{tabular}{lcc}
\hline Jenis & Frekuensi (f) & Persentase (\%) \\
Pekerjaan & 3 & 10 \\
\hline IRT & 6 & 19 \\
PNS & 20 & 65 \\
Pegawai & 2 & 6 \\
Swasta & 31 & 100 \\
Wiraswasta & & \\
\hline Total & & \\
\hline
\end{tabular}

Tabel 3 menunjukkan bahwa jenis pekerjaan dari responden terbanyak adalah pegawai swasta yaitu 20 orang (65\%).

\section{Karakteristik Responden Berdasarkan Umur}

Tabel 4

Distribusi Frekuensi Responden Berdasarkan Umur

\begin{tabular}{lll}
\hline Umur (th) & Frekuensi & $\begin{array}{l}\text { Persentase } \\
(\%)\end{array}$ \\
\hline $30-40$ & 25 & 81 \\
$41-50$ & 6 & 19 \\
\hline Total & 31 & 100 \\
\hline
\end{tabular}

Tabel 4 menunjukkan bahwa responden terbanyak berumur di antara 30-40 tahun yaitu 25 orang $(81 \%)$.

Kecemasan responden sebelum dan sesudah diberikan komunikasi terapeutik perawat

Tabel 5

Distribusi frekwensi tingkat kecemasan responden sebelum dan sesudah diberikan Komunikasi Terapeutik perawat

\begin{tabular}{llclc}
\hline Tingkat & \multicolumn{2}{c}{ Sebelum } & \multicolumn{2}{c}{ Sesudah } \\
\cline { 2 - 5 } Kecemasan & $\mathrm{f}$ & $\%$ & $\mathrm{f}$ & $\%$ \\
\hline Tidak cemas & 2 & 6 & 11 & 36 \\
$\begin{array}{l}\text { Kecemasan } \\
\text { ringan }\end{array}$ & 12 & 39 & 20 & 64 \\
& & & &
\end{tabular}

\begin{tabular}{lllll}
$\begin{array}{l}\text { Kecemasan } \\
\text { sedang }\end{array}$ & 17 & 55 & 0 & 0 \\
$\begin{array}{l}\text { Kecemasan } \\
\text { berat }\end{array}$ & 0 & 0 & 0 & 0 \\
Panik & 0 & 0 & 0 & 0 \\
\hline Total & 31 & 100 & 31 & 10 \\
\hline
\end{tabular}

Pada tabel 5 menunjukkan bahwa sebelum diberikan komunikasi terapeutik perawat prosentase terbanyak responden mengalami kecemasan sedang yaitu 17 orang( 55\%), sedang yang mengalami kecemasan ringan ada 12 orang $(39 \%)$. Ada dua orang responden ( $6 \%$ ) yang tidak mengalami kecemasan. Tidak ada responden sebelum diberikan komunikasi terapeutik mengalami kecemasan berat dan panik. Sesudah diberikan komunikasi terapeutik ternyata terjadi pergeseran tingkat kecemasan responden yaitu yang tidak mengalami kecemasan menjadi 11 orang $(36 \%)$, kecemasan ringan menjadi 20 orang(64\%),dan tidak ada responden yang mengalami kecemasan sedang, berat, dan panik. Dilihat dari frekwensi dan prosentase perubahan tingkat kecemasan dapat diduga komunikasi terapeutik perawat dapat menurunkan tingkat kecemasan responden.

\section{Rerata Tingkat Kecemasan Responden Sebelum Diberikan Komunikasi Terapeutik Perawat di Klinik THT RSD Mangusada Kabupaten Badung}

Tabel 6

Rerata Tingkat Kecemasan Responden Sebelum Diberikan KomunikasiTerapeutik Perawat di Klinik THT RSD Mangusada Kabupaten Badung

\begin{tabular}{lll}
\hline Perlakuan & $\begin{array}{l}\text { Nilai } \\
\text { rerata }\end{array}$ & $\begin{array}{l}\text { Tingkat } \\
\text { kecemasan }\end{array}$ \\
\hline $\begin{array}{l}\text { Sebelum } \\
\text { komunikasi } \\
\text { terapeutik }\end{array}$ & 21 & $\begin{array}{l}\text { Kecemasan } \\
\text { sedang }\end{array}$
\end{tabular}

Pada tabel 6 menunjukkan bahwa sebelum diberikan komunikasi terapeutik pada 31 orang responden didapat nilai rata-rata responden 21 dalam kategori kecemasan sedang.

Rerata Tingkat Kecemasan Responden Setelah Diberikan Komunikasi Terapeutik Perawat di 
Klinik THT RSD mangusada Kabupaten Badung

Tabel 7

Rearata Tingkat Kecemasan Responden Setelah diberikan Komunikasi Terapeutik Perawat di Klinik THT RSD Mangusada

Kabupaten Badung

\begin{tabular}{lll}
\hline Perlakuan & $\begin{array}{l}\text { Nilai } \\
\text { rerata }\end{array}$ & $\begin{array}{l}\text { Tingkat } \\
\text { kecemasan }\end{array}$ \\
\hline $\begin{array}{l}\text { Setelah } \\
\text { komunikasi } \\
\text { terapeutik }\end{array}$ & 15 & $\begin{array}{l}\text { Kecemasan } \\
\text { ringan }\end{array}$ \\
\hline
\end{tabular}

Pada tabel 7 menunjukkan bahwa setelah diberikan komunikasi terapeutik pada 31 orang responden didapat tingkat kecemasan menurun menjadi kategori kecemasan ringan dengan nilai rata-rata 15. Dapat dikatakan bahwa komunikasi terapeutik secara rata-rata menurunkan tingkat kecemasan responden yang anaknya menjalani tonsilektomi.

Pengaruh Komunikasi Terapeutik Perawat Terhadap Tingkat Kecemasan Orang Tua Pasien Sebelum Tonsilektomi Di RSD Mangusada Badung

Tabel 8

Analisis Data Sebelum dan Setelah Diberikan Komunikasi Terapeutik

\begin{tabular}{|c|c|c|c|c|c|c|c|}
\hline $\begin{array}{l}\text { Kelom } \\
\text { pok } \\
\text { perlak } \\
\text { uan }\end{array}$ & $\mathrm{n}$ & $\begin{array}{l}\text { Rer } \\
\text { ata }\end{array}$ & $\begin{array}{l}\mathrm{Be} \\
\mathrm{da} \\
\text { rer } \\
\text { ata }\end{array}$ & $\begin{array}{l}\text { M } \\
\text { ax }\end{array}$ & $\begin{array}{l}M \\
\text { in }\end{array}$ & $\begin{array}{l}\text { Stan } \\
\text { dar } \\
\text { Dev } \\
\text { iasi }\end{array}$ & $\mathrm{p}$ \\
\hline $\begin{array}{l}\text { Sebelu } \\
\text { m } \\
\text { komun } \\
\text { ikasi } \\
\text { terape } \\
\text { utik }\end{array}$ & & 21 & 6 & 27 & 12 & $\begin{array}{l}4.23 \\
8\end{array}$ & \\
\hline $\begin{array}{l}\text { Setela } \\
\text { h } \\
\text { komun } \\
\text { ikasi } \\
\text { terape } \\
\text { utik }\end{array}$ & 1 & 15 & & 20 & 11 & $\begin{array}{l}2.40 \\
8\end{array}$ & $\begin{array}{l}0,0 \\
01\end{array}$ \\
\hline
\end{tabular}

Pada tabel 8 menunjukkan bahwa dari 31 orang responden yaitu orang tua dari pasien yang akan dioperasi tonsilektomi nilai rerata kecemasan sebelum diberikan komunikasi terapeutik adalah 21. Artinya, rata-rata responden berada pada tingkat kecemasan sedang. Setelah diberikan komunikasi terapeutik rerata nilai kecemasannya adalah 15, yang artinya tingkat kecemasan responden rata-rata berada pada tingkat ringan. Perbedaan tingkat kecemasannya ini bermakna dan signifikan dengan bukti nilai $\mathrm{p}$ $=0,001<\alpha 0,05$.

\section{PEMBAHASAN}

\section{Rerata Tingkat Kecemasan Responden Sebelum Diberikan Komunikasi Terapeutik.}

Sebelum diberikan komunikasi teraupeutik rata-rata responden mempunyai tingkat kecemasan yang sedang dengan nilai adalah 21 . Penelitian sejalan dilakukan oleh Firmansyah \& Niar (2016), menunjukan kecemasan orang tua terhadap anaknya yang di pasang intravena sebagian besar kecemasan sedang yaitu 19 orang $(63,3 \%)$. Penelitian ini sejalan dengan penelitian Rohmah \& Qoumariah (2016) bahwa komunikasi terapeutik perawat menurunkan kecemasan keluarga pasien kritis, sebelum diberikan komunikasi terapeutik sebagian besar cemas berat $(83,5 \%)$.

Pencetus terjadinya kecemasan antara lain adalah penyakit kronis, trauma fisik, dan pembedahan. Pembedahan tersebut dapat dialami oleh siapa saja termasuk anak-anak. Penatalaksanaan tonsilektomi membawa konsekuensi psikologis, fisiologis, dan anatomis. Konsekuensi psikologis yang didapat pasien dan keluarganya diantaranya muncul rasa kecemasan (Lubis \& Afif, 2014). Kecemasan adalah kekhawatiran yang tidak jelas dan menyebar, yang berkaitan dengan perasaan tidak pasti dan tidak berdaya. Bagi orang tua yang anaknya ditonsilektomi merupakan suatu stressor yang dapat mengakibatkan suatu gangguan mental berupa kecemasan. Orang tua akan memikirkan bagaimana anaknya bila dioperasi pada operasi tonsilektomi. Mereka akan merasakan kecemasan, memikirkan kemungkinan-kemungkinan yang mengenai anaknya (Stuart, 2013). Seperti yang dikatakan oleh Suliswati (2015) ada beberapa faktor yang memengaruhi reaksi kecemasan yaitu tingkat pendidikan dan umur

Hasil penelitian menunjukan tingkat pendidikan responden terbanyak adalah SMA sederajat yaitu 15 orang (48\%). Sejalan dengan penelitian yang dilakukan oleh Slamet (2014), 
menunjukan sebagian besar pendidikan SMP sebanyak 13 orang $(40,6 \%)$. Pendidikan diperlukan untuk mendapatkan informasi misalnya hal-hal yang menunjang kesehatan, sehingga dapat meningkatkan kualitas hidup. Pendidikan dapat mempengaruhi seseorang termasuk juga perilaku seseorang akan pola hidup terutama dalam memotivasi untuk sikap berperan serta dalam pembangunan kesehatan. Makin tinggi tingkat pendidikan seseorang makin mudah menerima informasi sehingga semakin banyak pula pengetahuan yang dimiliki. Sebaliknya pendidikan yang kurang akan menghambat perkembangan sikap seseorang terhadap nilainilai baru yang diperkenalkan (Caninsti, 2013).

Hasil penelitian menunjukkan bahwa responden terbanyak berumur di antara 30-40 tahun yaitu 25 orang (81\%). Sejalan dengan penelitian yang dilakukan oleh Slamet (2014), menunjukan sebagian besar usia 31-40 tahun sebanyak 14 orang $(43,8 \%)$. Semakin cukup umur, tingkat kematangan dan kekuatan seseorang akan lebih matang dalam berpikir dan bekerja. Dari segi kepercayaan masyarakat, seseorang yang lebih dewasa akan lebih dipercaya dari orang yang belum dewasa. Hal ini sebagai akibat dari pengalaman dan kematangan jiwa. Makin tua umur seseorang makin konstruktif dalam menggunakan koping terhadap masalah yang dihadapi.

Hasil pengamatan peneliti rerata tingkat kecemasan orang tua pasien sebelum diberikan komunikasi terapeutik dalam kecemasan sedang. Kecemasan sedang pada orang tua yang anaknya akan dilakukan operasi tonsilektomi disebebkan orang tua kurang paham tentang prosedur operasi dan efek samping yang ditimbulkan setelah operasi. Hasil pengamatan peneliti berdasarkan kuesioner HARS sebagian besar orang tua tegang dan ketakutan sebelum anaknya dilakukan operasi. Perasaan cemas juga terlihat pada orang tua yang sangat mudah tersinggung pada saat diberikan penjelasan.

\section{Rerata Tingkat Kecemasan Responden Setelah Diberikan Komunikasi Terapeutik}

Setelah diberikan komunikasi terapeutik terjadi penurunan rata-rata tingkat kecemasan responden yaitu menjadi kecemasan ringan. Secara rata-rata memang terjadi penurunan tingkat kecemasan dari tingkat sedang menuju ringan. Keadaan ini bisa terjadi karena para responden telah mendapatkan pemahaman tentang manfaat tindakan operasi yang dilakukan dokter kepada anaknya. Penelitian Sebelumnya dilakukan oleh Rohmah \& Qomariah (2017) tentang komunikasi terapeutik perawat menurunkan kecemasan keluarga pasien kritis ( $\mathrm{p}$ $=0,001<\alpha \quad 0,05)$. Hidayah (2018) tentang penerapan komunikasi terapeutik terhadap pasien pre-operasi yang mengalami kecemasan di Rumah Sakit Ortopedi Prof. dr. R Soeharso Surakarta $(p=0,001<\alpha 0,05)$.

Komunikasi terapeutik merupakan komunikasi antar tenaga kesehatan dengan pasien, bertujuan untuk menolong proses penyembuhan pasien (Rezki, 2017). Komunikasi terapeutik termasuk komunikasi interpersonal dengan titik tolak saling memberikan pengertian antara perawat dengan pasien dan keluarga (Kasana,2018). Komunikasi terapeutik merupakan komunikasi antara perawat dengan orang tua pasien yang anaknya akan ditonsilektomi tentang permasalahan penyakit yang dialami pasien, tindakan yang akan dilakukan, akibat yang ditimbulkan oleh pasien tersebut, pengobatan yang akan didapatkan, serta efek dari penobatannya. Hal tersebut sesuai dengan apa yang dikatakan oleh Hawari (2012) bahwa kejelasan tentang kebermanfaatan tindakan dapat mengurangi kecemasan seseorang.

Hasil pengamatan peneliti responden telah mengerti apa yang akan dilakukan terhadap anak tersebut tidak menyebabkan kecacatan apalagi kematian, mereka akan dapat menerima tindakan tonsilektomi. Pemahaman yang sebaliknya yaitu tindakan tonsilektomi akan membuat anaknya menjadi lebih sehat menjadikan responden menggunakan akalnya untuk menjawab keraguan pada dirinya. Dengan demikian, kecemasan yang dialami akan menurun.

\section{Analisis Pengaruh Komunikasi Terapeutik Perawat Terhadap Tingkat Kecemasan Orang Tua Pasien}

Hasil penelitian menunjukan adanya pengaruh yang signifikan komunikasi terapeutik terhadap penurunan tingkat kecemasan responden yang anaknya akan menjalani tonsilektomi. Penelitian yang dilakukan oleh Nafdianto \& Armiyadi (2016) meneliti tentang komunikasi terapeutik dan kecemasan keluarga di ruang ICU RSTK-II Kesdam-IM Banda Aceh yang menemukan terdapat hubungan antara komunikasi terapeutik dengan tingkat kecemasan keluarga pasien di ruang intensive care unit rumah sakit TK II Kesdam Iskandar Muda Banda Aceh dengan nilai $\mathrm{p}$-value $0.012<\alpha=0.05$. penelitian 
Suselo., Rompas, \& Wowiling (2017) pada penelitian tentang hubungan komunikasi terapeutik perawat dengan tingkat kecemasan orang tua saat pemasangan infus pada anak di RSUP Prof. Dr. R. D. Kandou Manado menemukan adanya korelasi yang postif dan bermakna komunikasi terapeutik dengan tingkat kecemasan $(p)=0,001 \leq \alpha=0,05$.

Penggunaan komunikasi terapeutik untuk mengurangi kecemasan sudah banyak dilakukan pada rumah sakit. Komunikasi ini memberikan pemahaman yang jelas kepada pasien atau keluarganya tentang berbagai tindakan yang akan dilakukan kepada pasien. Berbagai keraguan pasien atau keluarganya akan dijelaskan sehingga mereka benar-benar paham akan kebermanfaatan tindakan yang akan dilakukan. Dengan demikian, tidak terjadi lagi keragu-raguan baik dari pasien atau tenaga kesehatan yang akan bekerja (Caninsti, 2013; Mulyadi, \& Lolong, 2015).

Bagi orang tua yang anaknya ditonsilektomi merupakan suatu stressor yang dapat mengakibatkan suatu gangguan mental berupa kecemasan. Kecemasan orang tua pasien sebelum operasi tonsil dapat dikurangi dengan komunikasi terapeutik. Tahapan-tahapan komunikasi terapeutik adalah tahap pra interaksi, tahap perkenalan dan orientasi, tahap kerja dan tahap terminasi. Teknik komunikasi terapeutik yang bisa diterapkan oleh perawat ke orang tua pasien yang anaknya akan ditonsilektomi yaitu mendengarkan dengan penuh perhatian, menanyakan pertanyaan dengan pertanyaan terbuka, mengulang ucapan pasien menggunakan kata sendiri, klasifikasi, memfokuskan, menyampaikan hasil observasi, menawarkan informasi, diam, menganjurkan untuk meneruskan pembicaraan, menempatkan kejadian secara teratur, menganjurkan pasien untuk menguraikan persepsinya, dan refleksi (Muhlisin \&Ichsan, 2018); (Putri, 2016); (Pieter \& Saleh, 2012).

Kecemasan yang dialami orang tua pada anaknya yang akan di operasi tonsilektomi dikarenakan kurang pahamnya tentang prosedur operasi, komplikasi operasi dan perawatan pasca operasi. Hasil pengamatan peneliti komunikasi terapeutik yang diberikan perawat kepada orang tua pasien yang anaknya akan melakukan tonsilektomi merupakan suatu bentuk intervensi keperawatan dalam menurunkan kecemasan pasien dan keluarga terutama orang tua. Komunikasi terapeutik juga menumbuhkan pasien atau keluarga terhadap petugas kesehatan dalam melakukan suatu tindakan yaitu tonsilektomi.

\section{KESIMPULAN}

Ada pengaruh yang signifikan dan bermakna komunikasi terapeutik terhadap penurunan tingkat kecemasan responden sebelum anaknya dilakukan tindakan tonsilektomi di RSD Mangusada Badung.

\section{DAFTAR PUSTAKA}

Akbar,A.P. (2013). Gambaran Kepuasan Pasien Terhadap Pelaksanaan Komunikasi Terapeutik Perawat Di Instalasi Rawat Inap RSUD Labuang Baji Makasar Tahun 2013. Jurnal Universitas Hasanudin, 1-11

Annisa, D. F., \& Ifdil, I. (2017). Konsep Kecemasan (Anxiety). Konselor.

Aprilia, A, \& Muthadi, A. (2018). Efek Jangka Panjang Tonsilektomi Dan Adenoidektomi Pada Anak. Jurnal Farmaka Suplemen, (6) 2,1-6

Apriansyah, A. (2015). Hubungan antara Tingkat Kecemasan Pre-Operasi dengan Derajat Nyeri pada Pasien Post Sectio Caesarea di Rumah Sakit Muhammadiyah Palembang Tahun 2014. Jurnal Keperawatan Sriwijaya.

Aswad, S., Mulyadi, \& Lolong, J. (2015). Hubungan Komunikasi Terapeutik Perawat Dengan Kepuasan Pasien Di Instalasi Gawat Darurat RSUD Dr. H. Chasan Boesoirie Ternate. Jurnal Keperawatan.

Babazade, R., Dogangun, B., Bozkurt, P.S., Gungor, G., \& Kayaalp, L. (2015). Association between anxiety level of child with parental and patient factors during preoperative anesthesi visit. The open Psychiatry and Nursing Jorurnal, 9, 11-16.

Caninsti, R. (2013). Kecemasan dan Depresi pada Pasien Gagal Ginjal Kronis yang Menjalani Terapi Hemodialisis. Jurnal Psikologi Ulayat.

Efianingrum, A. (2010). Metode Penelitian Kualitatif dan Kuantitatif. Seminar Sosisologi.

Firmansyah, A., \& Niar. (2016). Hubungan Pemberian Informed Consent Dengan Tingkat Kecemasan Orang Tua Anak Yang Di Terapi Intravena Di Ruang Udg Rsud Polewali Mandar. Jurnal Kesehatan: Bina Generasi, 9(9)

Ghufron, M. N., \& Risnawita, R. (2011). Teoriteori psikologi. In Yogyakarta: Ar-Ruzz Media. $\quad$ https://doi.org/10.1088/00318949/1993/T49B/040 
Handayani, R. (2018). Faktor-Faktor Yang Berhubungan Dengan Tingkat Kecemasan Menjelang Persalinan Pada Ibu Primigravida Trimester III di Wilayah Kerja Puskesmas Lubuk Buaya Padang Tahun 2012. NERS Jurnal Keperawatan.

Hawari, D. (2011). Manajemen Stres Cemas dan Depresi. Jakarta :Balai Penerbit FKUI.

Hawari, D. (2013). Stres, Cemas dan Depresi. Jakarta: EGC.

Hidayah, A. (2018). Penerapan Komunikasi Terapeutik Terhadap Pasien Pre-Operasi Yang Mengalami Kecemasan Di Rumah Sakit Ortopedi Prof. Dr. R Soeharso Surakarta. Jurnal Bimbingan Konseling

Irianto, A. D., Kristiyawati, S. P., \& Supriyadi. (2014). pengaruh hipnoterapi terhadap penurunan tingkat kecemasan pada pasien yang menjalani kemoterapi di rs telogorejo semarang. jurnal ilmu keperawatan dan kebidanan.

Itje Sela, E., \& Hartati, S. (2012). Pengenalan Jenis Penyakit THT Menggunakan Jaringan Learning Vector Quantization. Seminar Riset Teknologi Informasi (SRITI).

Kasana, N. (2018). Hubungan antara komunikasi terapeutik dengan tingkat kecemasan pada pasien pre operasi sectio caesarea di ruang ponek rsud karanganyar. Jurnal Kesehatan.

Liza,M.N., Suryani, M., \& Meikawati, W. (2014). Efektifitas Komunikasi Terapeutik Perawat Terhadap Tingkat Kecemasan Orangtua Anak Pre Operasi Di Rsud Tugurejo Semarang. Jurnal Ilmu Keperawatan dan Kebidanan, 1-8

Lubis, P.Y \& Afif A.A. (2014). Tingkat kecemasan orangtua dengan anak yang akan dioperasi. E-Journal Keperawatan, 2 (3), 154-159.

Lukman,H. P., Prabowo, T., \& Indah,Y. B. (2013). Komunikasi Terapeutik Perawat Berhubungan dengan Tingkat Kepuasan Pasien di Puskesmas Dukun Magelang. Jurnal Ners Dan Kebidanan Indonesia.

Martono, N. (2011).Perubahan Sosial Budaya. Depok: PT Rajagrafindo Persada

Martono, N. (2014). Metode Penelitian Kuantitatif Analisis Isi dan Anlisis Data Sekunder. Depok: PT Rajagrafindo Persada

Nafdianto., \& Armiyadi, M. (2016). Komunikasi Terapeutik Dan Kecemasan Keluarga Di Ruang ICU RSTK-II Kesdam-IM Banda Aceh. Jurnal Ilmiah Mahasiswa Fakultas Keperawatan. 1(1)
Notoatmodjo. (2012). Promosi Kesehatan dan Prilaku Kesehatan. Jakarta: Rineka Cipta.

Notoatmodjo, S. (2010). Promosi Kesehatan, Teori \& Aplikasi.Jakarta: Rineka Cipta.

Notoatmodjo, S. (2014). Metode Penelitian Survei. Jakarta: Rineka Cipta.

Nursalam. (2011). Manajemen Keperawatan. Jakarta:Salemba Medika

Nursalam. (2014). Manajemen Keperawatan Aplikasi Dalam Praktik Keperawatan Profesional.Jakarta: Salemba Medika.

Nursalam. (2017). Metodologi Penelitian Ilmu Keperawatan: Pendekatan Praktis.Jakarta:Salemba Medika

Palandeng, A. C. T., Tumbel, R. E. C., \& Dehoop, J. (2014). Penderita Tonsilitis Di Poliklinik THT-Kl Blu Rsup Prof. Dr. R. D. Kandou Manado Januari 2010-Desember 2012. eclinic.

Perhimpunan Dokter Spesialis T. H. T. B. K.-L. (2013). Panduan Praktik Klinis Panduan Praktik Klinis Prosedur Tindakan Clinical Pathways. Pengurus Pusat Perhati-KL.

Potter,P.A, \& Perry, A.G.(2013). Pundamental Of Nursing. St.Louis, Missouri: Elsevier Mosby

Pieter, H. Z., \& Lubis, N. L. (2010). Pengantar Psikologi dalam Keperawatan. Jakarta:Kencana

Ramschie, M., Pelealu, O. C., \& Tumbel, R. E. C. (2015). tindakan operasi tht-kl di blu rsup prof dr. r.d. kandou malalayang. e-clinic.

Randel, A. (2011). AAO-HNS Guidelines for Tonsillectomy in Children and Adolescents. American Family Physician.

Rezki, I. M., Lestari, D. R., \& Setyowati, A. (2017). Komunikasi terapeutik perawat dengan tingkat kecemasan keluarga pasien di ruang intensive care unit. Jurnal Dunia Keperawatan.

Rohmah, M., \& Qomariah, N.S. (2017). komunikasi terapeutik perawat menurunkan kecemasan keluarga pasien kritis. Journal Of Ners ommunity, 8(2), 144-151

Riskesdas. (2013). Riset Kesehatan Dasar, RISKESDAS. Jakarta: Balitbang Kemenkes RI

Sanpardi, G. P., Dehoop, J., \& Mengko, S. K. (2015). survei kesehatan tenggorok pada masyarakat pesisir pantai bahu. e-CliniC.

Setiadi. (2007). Konsep Dan Penulisan Riset Keperawatan.;2007. Yogyakarta: Graha Ilmu

Shirley, P.J., Thompson, N., Kenward, M., 
\&Johnston, G. (2010). Parental anxiety before elective surgery in children. Nursing Journal, 53, 956-959

Sigalingging, G. (2013). Hubungan komunikasi terapeutik perawat dengan tingkat kecemasan orang tua pasien di Ruang Intensif Rumah Sakit Columbia Asia Medan. Jurnal Darma Agung

Siti, M., Zulpahiyana, \& Indrayana, S, (2016). Komunikasi Terapeutik Perawat Berhubungan dengan Kepuasan Pasien with The Patient' s Satisfaction. Journal Ners and Midwifery Indonesia, 4(1),30-34

Slamet, S.P.R. (2014). Pengaruh Komunikasi Terapeutik Terhadap Tingkat Kecemasan Pada Keluarga Pasien Yang Dirawat Di Ruang PICU RSUP Dr. Sardjito Yogyakarta.

Soetjiningsih, Maulana, H. D., Foscht, T., Angerer, T., Swoboda, B., Notoadmojo S.,\& Bambang, M. A. W. (2012). Metode Penelitian Kesehatan. Qualitative Marktforschung. https://doi.org/10.1007/978-3-8349-94417 16

Stuart, G. W. (2013). Principle and practice of Psychiatric nursing, 10th Edition. In St. Louis.

Sugiyono. (2010). Metode Penelitian Kombinasi (Mixed Methods). Bandung: Alfabeta.

Suselo, R.R., Rompas, S., \& Wowiling, F. (2017). hubungan komunikasi terapeutik perawat dengan tingkat kecemasan orang tua saat pemasangan infus pada anak di RSUP Prof. Dr. R. D. Kandou Manado. E-Journal Keperawatan, 5(1), 1-4

Susilo, N. (2011). Pendidikan Kesehatan dalam Keperawatan. Muha Medika:Yogyakarta

Turnip, M. (2015). Sistem Pakar Diagnosa Penyakit THT Menggunakan Metode Backward Chaining. In Riau Journal Of Computer Science.

Tanjung, F.F \& Imanto, M. (2016). Indikasi tonsilektmi pada laki-laki usia 19 tahun dengan tonsilitis kronis. Jurnal Madula Unila, 5(2), 1-4 